\title{
THE ROMAN METROPOLIS CARNVNTVM REVEALS MORE GOLD COINS
}

\begin{abstract}
By presenting new evidence on gold coin finds, this paper is discussing the possibility that the Roman metropolis of Carnuntum - a 10 sqkm archaeological site - may be one of the highest providers of the single gold coin finds among the Roman sites.
\end{abstract}

Keywords: Gold coins, Carnuntum, aureus, solidus.

$\mathbf{0}$ ne of the benefits to create, nowadays, large digital databases was the possibility to organise the inventory of large museum collections.

This was the case for the coin collection of the Archaeological Park Carnuntum (Austria) that host at the moment one of the largest collections of ancient coins found within site, circa 100,000 pieces.

During the process of inserting the numismatic data in the Technical Museum System (TMS) application we noticed the high number of gold coins kept in this collection, 148 pieces.

Following a convergent approach between the Archaeological Park Carnuntum and private collectors, a book dedicated to gold finds found within the area of Carnuntum was published in $2014 .^{1}$

Two hundred and two gold coins, covering a chronological segment of 1,500 years, from the Celts to mid- $15^{\text {th }}$ century AD, were fully illustrated and described. By far, the largest number is offered, as one expects for a Roman metropolis such was Carnuntum (see maps 1 and 2), 148 coins starting with Caesar and ending, conventionally, with the coin of Theodosius II issued in AD 425-429. ${ }^{2}$

Certainly, such a large number of gold coins from one site only although the Roman site spread on $10 \mathrm{sqkm}$ - may raise some suspicions on the findspots. We cannot totally exclude the hypothesis that one or more gold hoards may have been dispersed among locals. Secondly, shall we question the credibility of the statements of the private collectors? In the second case, the acquisitions of private collections from the finders themselves or their heirs reveal the presence of old labels or diaries/agendas mentioning the findspots.

The present paper is presenting three new cases of single gold coin finds coming from private sources (collection and acquisitions), in which the findspot is precisely mentioned but for obvious reason we mention just the site, Carnuntum.

GĂZDAC/HUMER/POLLHAMMER 2014.

2 GĂZDAC/HUMER/POLLHAMMER 2014, 9 and the Catalogue.

\section{Cristian Găzdac \\ Institute of ArchaeologyCluj-Napoca cgazdac2000@yahoo.co.uk}

\section{Eduard Pollhammer}

Archaeological Park Carnuntum,

Petronell-Carnuntum

eduard.pollhammer@noel.gv.at

Werner Melchart

Bruckneudorf

werner.melchart@gmx.at

DOI: $10.14795 /$ j.v6i2.401

ISSN $2360-266 \mathrm{X}$

ISSN-L 2360 - 266X 


\section{VESPASIANVS}
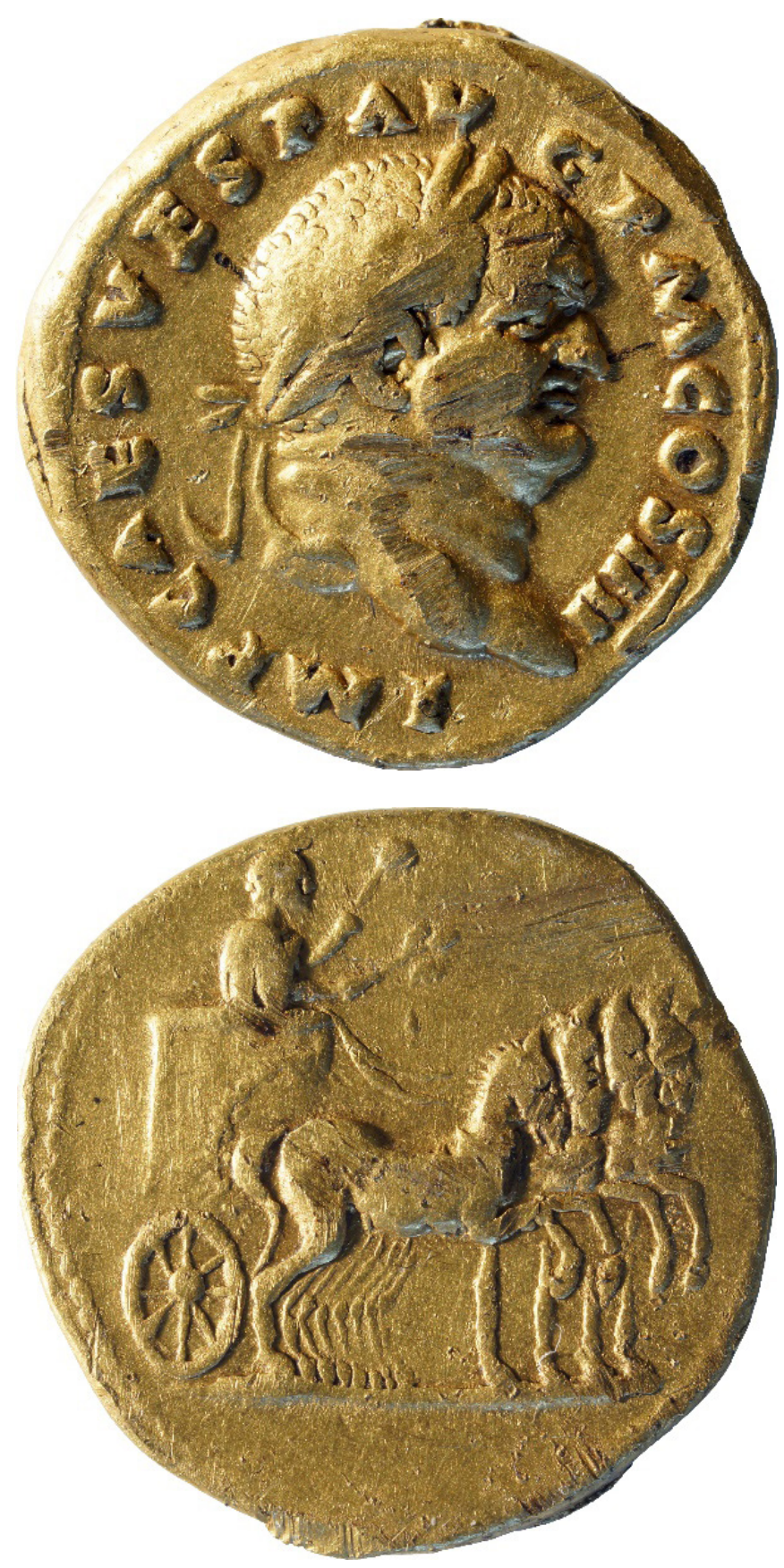

Denomination: aureus

Mint: Rome

Dating: AD 72-73

Axis: 6; Weight: $7.2 \mathrm{~g}$; Diameter: $19.2 \mathrm{~mm}$

Obverse: IMP CAES VESP A-VG P M COS IIII

Head of Vespasian, laureate, right.

Reverse: No legend.

Vespasian standing in quadriga, right, holding branch and scepter.

Catalogue: RIC II.1, 364

Findspot: Carnuntum

Place of keeping: Archaeological Park Carnuntum, inv. no. MC 52035

The obverse presents traces of modern alternations at the time of discovery.

\section{TRAIANVS}
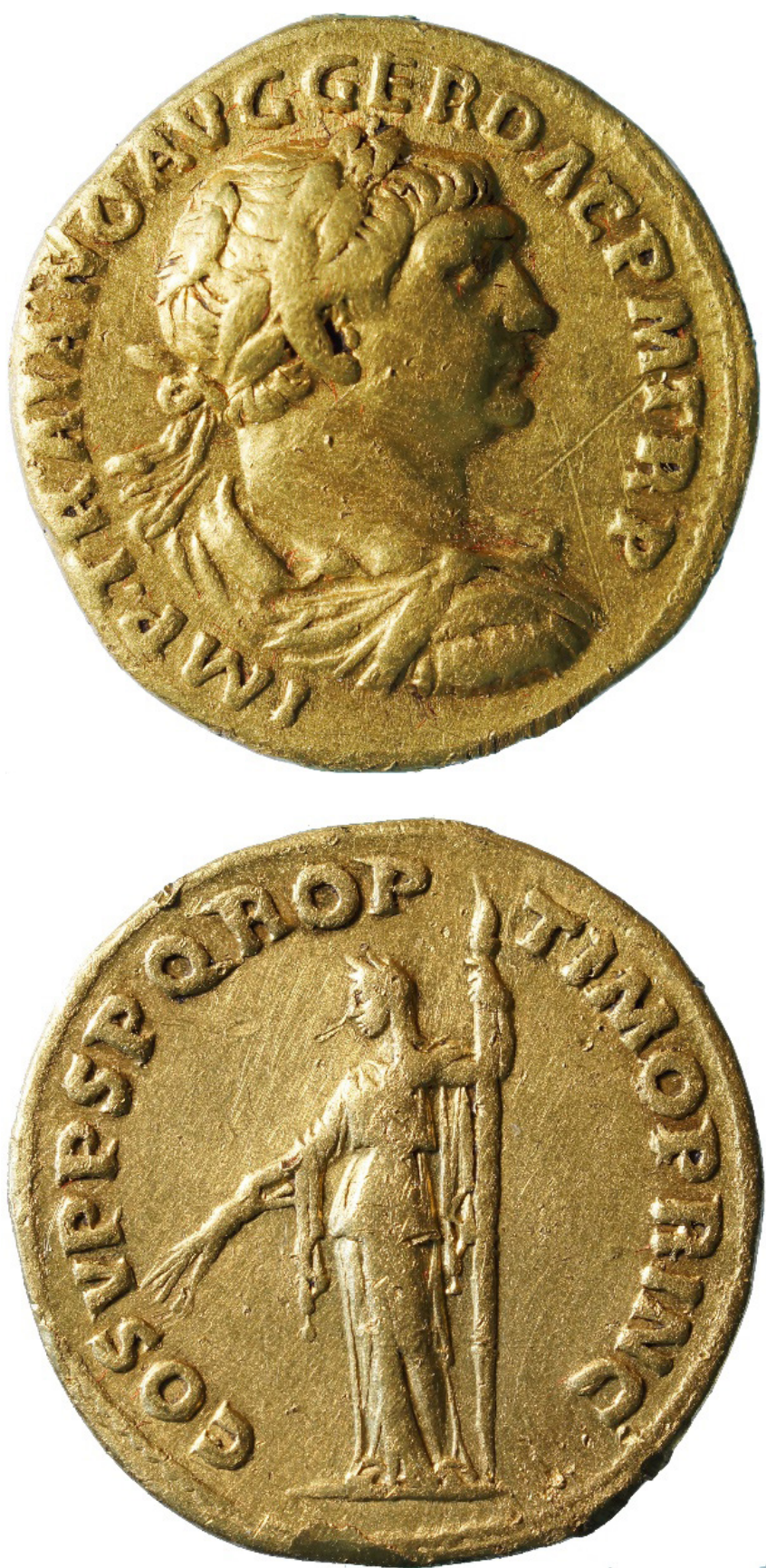

Denomination: aureus

Mint: Rome

Dating: AD 108-110

Axis: 7; Weight: 7.4 g; Diameter: $19.2 \mathrm{~mm}$

Obverse: IMP TRAIANO AVG GER DAC P M TR P

Bust of Trajan, laureate, draped, right.

Reverse: COS V P P S P Q R OP-TIMO PRINC

Ceres, draped, standing left, holding corn-ears pointed down in right hand and long straight torch in left.

Catalogue: RIC II, 109; MIR 14, $291 \mathrm{f}$

Findspot: Carnuntum

Place of keeping: Private collection

A well-preserved coin with few modern scratches on surfaces. 


\section{CONSTANTIVS II}
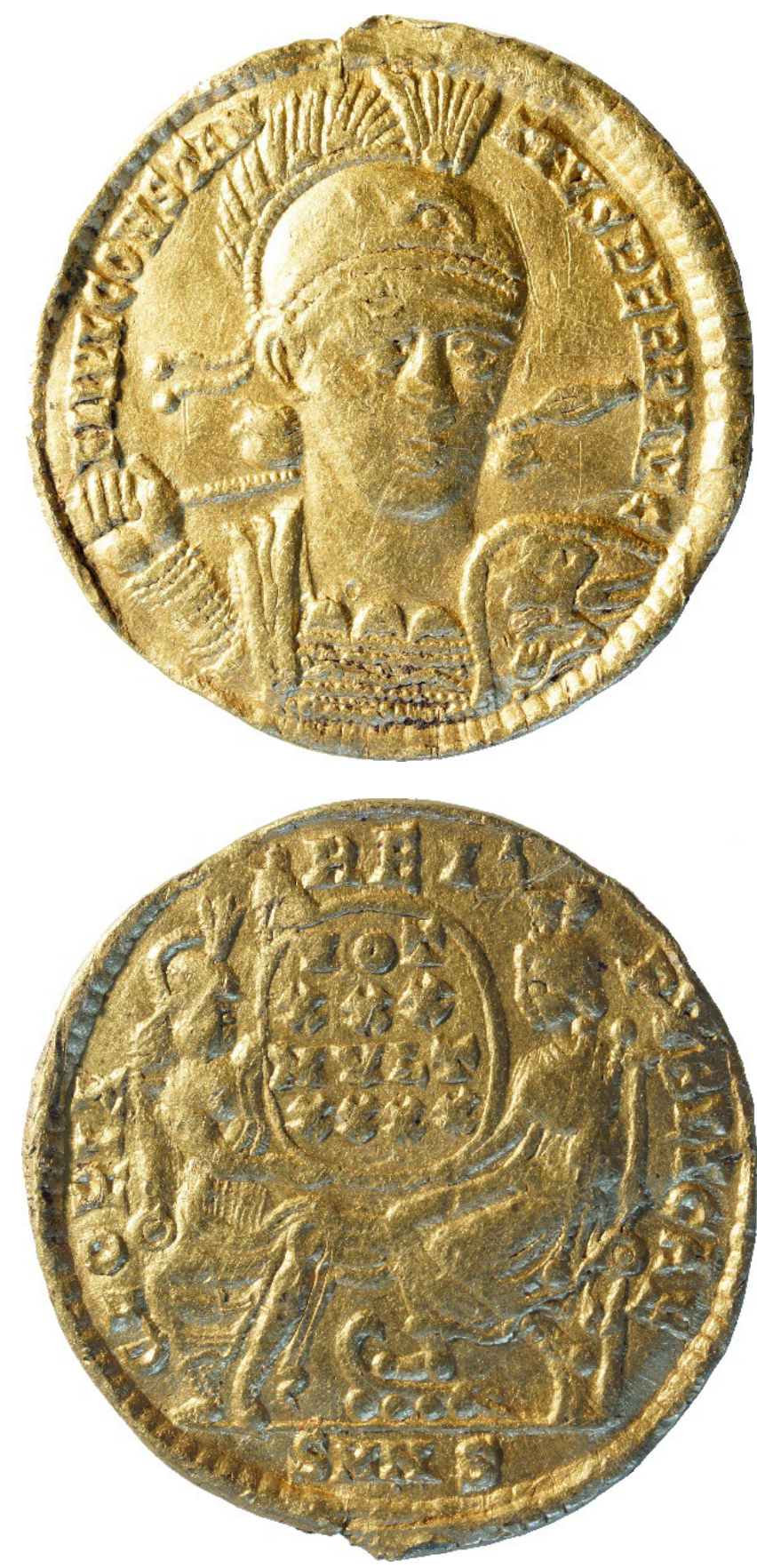

Denomination: solidus

Mint: Nicomedia

Dating: AD 351-355

Axis: 6; Weight: $4.2 \mathrm{~g}$; Diameter: $20.5 \mathrm{~mm}$

Obverse: FL IVL CONSTAN-TIVS PERP AVG

Bust of Constantius II, pearl-diademed, wearing crested and diademed helmet, cuirassed, facing front, holding spear diagonally over right shoulder in right hand and shield decorated with a horseman trampling an enemy in left hand.

Reverse: GLORIA - REI - PVBLICAE; -/-//SMNS

Roma, helmeted, draped, enthroned front, and Constantinopolis, draped, enthroned left, head left, supporting a shield inscribed VOT/XXX/MVLT/XXXX; Roma holding spear in left hand; Constantinopolis holding sceptre in left hand, her right foot on prow. Catalogue: RIC VIII (Nicomedia), 74

Findspot: Carnuntum (discovered on August 6, 1986) Place of keeping: Archaeological Park Carnuntum, inv. no. MC 52036

A well-preserved coin with few modern scratches on surfaces.

Certainly, the presentation of another three single Roman gold coin finds does not have a strong impact on the monetary history of the Roman Empire.

However, they are important for the wonderful state of preservation that point out the high level of numismatic art in the Roman Empire, especially for gold coinage. At the same time, the information on their exact findspot and their statute of single coin finds seems to confirm the hypothesis that Carnuntum can provide us with numerous single gold coin finds.

\section{ACKNOWLEDGEMENTS}

The research on the hoard under study was carried out within the research grants UEFISCDI PN-III-P4-IDPCE-2016-0021.

\section{REFERENCES}

\section{GĂZDAC/HUMER 2013}

Găzdac, C./Humer, F., Living by the Coins. Roman life in the light of coin finds and archaeology (Vienna: Hollitzer Wissenschaftlicher Verlag).

GĂZDAC/HUMER/POLLHAMMER 2014

Găzdac, C./Humer, F./Pollhammer, E., In the Shadow of the Heathens' Gate. The Black Book of the Gold Coins from MIR 14 Carnuntum (Cluj-Napoca: Mega Publishing House).

Woytek, B., Die Reichsprägung des Kaisers Traianus (98117) [Moneta Imperii Romani 14] (Wien: Verlag der Österreichischen Akademie der Wissenschaften, 2010). RIC II.1

Amandry, M./Buttrey, Th. V./Carradice, I., The Roman imperial coinage. vol. 2., part 1. From AD 69-96, Vespasian to RIC II Domitian (London: Spink, 2007).

Mattingly, H./Sydenham, E. A., The Roman imperial coinage. RIC VIII Vol. 2. Vespasian to Hadrian (London: Spink, 1972).

Kent, J. P. C., The Roman imperial coinage. Vol. 8. The family of Constantine I: A.D. 337-364 (London: Spink, 1981). 